\title{
Growth pattern in children with beta-thalassemia major and its relation with serum ferritin, IGF1 and IGFBP3
}

\author{
Beta-talasemi majorlu çocuklarda büyüme şekli ve serum ferritin, IGF1 ve IGFBP3 ile ilişkisi
}

\author{
Mona Ramadan Nasr, Nermin Ali Ebrahim, Manal Sayed Ramadan, Omnia Salahedin
}

Pediatric Department and Clinical Pathology Laboratory of Ahmed Maher Teaching Hospital, Cairo, Egypt

\begin{abstract}
Objectives: Growth impairment in children with Betathalassemia major (BTM) has several possible etiologies including excess iron overload and endocrinologic abnormalities. We aimed to assess growth in children with BTM and its relation with serum ferritin, thyroid hormones, IGF1 and IGFBP3.
\end{abstract}

Materials and methods: Thirty-three children with BTM and 30 healthy children (control group) matched in age, sex and height were subjected to full clinical history and examination, including anthropometric measurements. Fasting blood samples from both groups were taken for complete blood counts, fasting blood sugar, liver function tests, serum ferritin, thyroid profiles, IGF1 and IGFBP3. Bone ages for both groups were determined radiologically.

Results: A total of $57.6 \%$ of BTM group had retarded linear growth and $45.5 \%$ of them were with delayed puberty. There was statistical significant decrease in upper/ lower segment $(\mathrm{U} / \mathrm{L})$ ratio in the BTM group compared to the control group $(p=0.035)$. No apparent hypothyroidism was found in the thalassemia group, but significant decreases were found in both IGF1 and IGFBP3 levels of the thalassemia group compared with the control group $(p=0.022$ and $p=0.037$, respectively). There was a significant correlation between T4 and U/L ratio $(p<0.05)$; IGF1 was significantly correlated with height, duration of transfusions and duration of chelation $(p<0.05)$. No significant correlation was found between serum ferritin and other variables of the patients.

Conclusions: Growth retardation in children with BTM is evident despite regular transfusions and chelation therapy, especially in children with older age and the cause is mainly in growth hormone-IGF1 and IGFBP3 axis. J Clin Exp Invest 2012; 3(2): 157-163

Key words: Beta-thalassemia major, children, growth, thyroid profile, IGF1, IGFBP3, ferritin

\section{ÖZET}

Amaç: Beta-talasemi major'lu (BTM) çocuklarda büyüme geriliği aşırı demir yükü ve endokrinolojik anormallikleri de içeren birçok muhtemel etyoloji nedeniyledir. Biz BTM'li çocuklarda büyümeyi ve serum ferritin, tiroid hormonları, IGF1 ve IGFBP3 ile ilişkisini araştırmayı amaçladık.

Gereç ve yöntem: Beta-talasemi majorlu 33 çocuk ve yaş, cinsiyet ve boy bakımından eşleştirilmiş 30 sağlıklı kontrol grubu çocuk için tam bir öykü ve fizik muayene yapılarak, antropometrik ölçümleri alındı. Her iki grupta açlık kan örnekleri alınarak tam kan sayımı, açlık kan şekeri, karaciğer fonksiyon testleri, serum ferritin, tiroid profile, IGF1 ve IGFP3 düzeyleri çalışıldı. Her iki grubun kemik yaşı radyolojik olarak belirlendi.

Bulgular: Beta-talasemi major grubunda boy kısalığı $\% 57.6$ ve gecikmiş puberte \% 45.5 oranında saptandı. Üst/Alt ekstremite oranı BTM grubunda kontrollere nazaran anlamlı düşük bulundu $(p=0.035)$. Talasemi grubunda açık hipotiroidi görülmedi ancak BTM grubunda IGF1 ve IGFBP3 düzeyleri kontrollerden anlamlı düşük bulundu (sırasıyla, $p=0.022$ ve $p=0.037$ ). T4 ile üst/alt ekstremite oranı arasında anlamlı bağıntı mevcuttu. IGF1, boy, transfüzyon süresi ve şelasyon süresi ile anlamlı ilişkili bulundu. Serum ferritin ile diğer değişkenler arasında anlamlı bir korelasyon saptanmadı.

Sonuç: Beta-talasemi major'lu çocuklarda düzenli transfüzyonlar ve şelasyon tedavisine ragmen özellikle büyük çocuklarda büyüme geriliği belirgindir ve bunun nedeni asıl olarak büyüme hormone-IGF1 ve IGBP3 eksenindedir.

Anahtar kelimeler: Beta-talasemi major, çocuklar, büyüme, tiroid fonksiyonları, IGF1, IGFBP3, ferritin 


\section{INTRODUCTION}

Beta-thalassemia major (BTM) is a severe hemolytic anemia and it is the most common single gene abnormality. It has over 200 mutations, most of them are very rare, and approximately 20 common alleles constitute $80 \%$ of the known thalassemia word wide. Approximately, $3 \%$ of the world population carries genes of beta-thalassemia. ${ }^{1}$ Many complications of BTM are the result of increased iron deposition from repeated blood transfusion. The accumulation of iron in different tissues causes organ damage affecting mainly endocrine glands, heart and liver. ${ }^{2}$ The most prominent endocrine complication is failure of normal pubertal development and growth retardation. ${ }^{3}$

Growth failure has been attributed to growth hormone $(\mathrm{GH})$ (hypothalamic and/or pituitary), insulin-like growth factor 1 (IGF-1), insulin-like growth factor binding protein3 (IGFBP3) deficiency, hypothyroidism, delayed sexual maturation and to bone disorders caused by desferoxamine (DFX) toxicity. ${ }^{4}$ Short stature in children with BTM could be due to GH-IGF1 axis dysfunction and DFX induced bone dysplasia. ${ }^{5}$

The nitrogen actions of $\mathrm{GH}$ are mediated through increases in the synthesis of IGF-1, a single chain peptide with 70 amino acids coded by a gene on the long arm of chromosome 12. IGF-1 circulates bound to several binding proteins; the major one is a $150 \mathrm{kd}$ complex IGFBP3, which is decreased in $\mathrm{GH}$ deficient children. ${ }^{6}$

In this study, we aimed to assess growth in children with BTM and its relation to serum ferritin, thyroid hormones, IGF-1 and IGFBP3.

\section{MATERIALS AND METHODS}

The study included 33 children diagnosed as BTM clinically and by hemoglobin electrophoresis, 19 males and 14 female aged between 5 and 17 years as well as 30 age, sex and height matched healthy children (control group); all were attending the pediatric department of Ahmed Maher Teaching hospital from January 2009 to January 2010. All were fulfilling the inclusion criteria, which were age between 3 and 18 years, not suffering any serious hepatic, renal or cardiac disease and not having diabetes mellitus or serious infections.

The exclusion criteria were patients with anemia other than BTM, short stature due to other chronic systemic disease or hereditary bone dysplasia.
Written informed consent was taken from the parents and/or the patients and the controls themselves after explaining the aim of the study. The ethical committee of the general organization of teaching hospitals and institutes (GOTHI) approved the study.

\section{All patients and controls were subjected to the following}

1- Full history taking and clinical examination including anthropometric measurements and pubertal assessment by Tunner stage to all patients and controls above ten years.

\section{2- Laboratory investigations including;}

A- Complete blood counts (CBC), liver function and renal function tests, fasting blood glucose and 2 hours postprandial.

B- Serum ferritin levels using the method of White et al $1986{ }^{7}$ by enzyme immunoassay (EIA-1872 kits from DRG International Inc., USA.

C- Hormonal assay for T3, T4 and TSH using the method of Gruhun et al, 1987. ${ }^{\text {IGF-1 }}$ and IGFBP3 using the commercially available enzyme linked immunosorbent assay (ELIZA) kits of DSL (USA).

3- Imaging study included wrist X-ray to assess bone age and abdominal ultrasound for all patients and some of the controls. Bone age was assessed according to Greulich and Pyle $1974 .{ }^{9}$

\section{Statistical analysis}

Statistical analysis of the results was done using SPSS version16 (SPSS Inc, Chicago, USA); using mean and standard deviation for descriptive data, Chi-square and t-Student tests for significance testing; and Pearson correlation coefficient $r$ to correlate different variables. A $p$ value less than 0.05 was considered significant.

\section{RESULTS}

The results of this study revealed that the mean age of the BTM group was $10.1 \pm 3.3$ years, the mean duration of the disease was $8.4 \pm 3.2$ years, with mean frequency of blood transfusion per month was $1.5 \pm 0.7$ and mean duration of chelation therapy 5 \pm 2.7 years. $19(57.6 \%)$ of them were below the $5^{\text {th }}$ centile for age and sex as regard height and weight [BTM group 1]; the rest of this group 14 (42.4\%), their height and weight were between 5th and 50th centile for age and sex [BTM group 2]. From the control group $18(60 \%)$ were below the 5 th centile for age and sex as their height and weight [control 
group 3], the rest of the controls were between 10th and 60th centile for age and sex as regard their height and weight [control group 4]. Table 1 shows the clinical and laboratory data of BTM group and the control group. $45.5 \%$ of BTM patients were with delayed puberty rather than pre-pubertal. There was statistical significant decrease in upper/lower segment (U/L) ratio in the BTM group compared to the control group $(p=0.035)$. No apparent hypothyroidism was found in the thalassemia group nor the control group, but there was a statistical significant decrease in both IGF1 and IGFBP3 in the thalassemia group compared to the control group $p=0.022$ and $p=0.037$ respectively. Table 2 compares the clinical and the laboratory data of the two BTM groups. The group with retarded growth was older, but the difference was not significant. Table 3 shows the clinical and the laboratory data of BTM group 1 and their control group 3. BTM group 1 were older than their control group $3(p=0.042)$ and $73.7 \%$ of them were with delayed puberty compared to their control group $3(p=0.000)$. Table 4 shows the clinical and the laboratory data of BTM group 2 and their control group 4. Table 5 shows correlation between the clinical parameters of BTM group and the studied laboratory parameters. There was statistical significant correlation between T4 and U/L ratio $(p<0.05)$; IGF1 was statistically significantly correlated with height, duration of transfusion and duration of chelation, where correlation coefficient $r$ was significant at 0.05 level. Serum ferritin was not significantly correlated with any other variable of the patients.

Table 1. Clinical and laboratory data of beta-Thalassemia major (BTM) group and the control group

\begin{tabular}{|c|c|c|c|}
\hline Groups, Variables & BTM group $(n=33)$ & Control group $(n=30)$ & $\mathrm{P}$ \\
\hline Age $($ mean $\pm S D)$ years & $10.2 \pm 3.3$ & $9.8 \pm 3.5$ & 0.876 \\
\hline Male/ female ratio & $19 / 14$ & $17 / 13$ & 0.766 \\
\hline Height (mean $\pm \mathrm{SD}$ ) cm & $123.3 \pm 16.3$ & $128.6 \pm 21$ & 0.645 \\
\hline Wight (mean \pm SD) kg & $25 \pm 7.1$ & $26.4 \pm 5.5$ & 0.565 \\
\hline $\mathrm{BMI}($ mean $\pm \mathrm{SD})$ & $16.3 \pm 2$ & $17.2 \pm 1.4$ & 0.874 \\
\hline US/LS ratio (mean \pm SD) & $0.84 \pm 0.2$ & $1.3 \pm 0.1$ & $0.035^{*}$ \\
\hline \multicolumn{4}{|l|}{ Pubertal stage: } \\
\hline Pre-pubertal (\%) & $8(24)$ & $18(60)$ & $0.023^{*}$ \\
\hline Pubertal (\%) & $10(30.3)$ & $12(40)$ & \\
\hline Delayed puberty (\%) & $15(45.5)$ & 0 & $0.000^{*}$ \\
\hline Number with splenectomy (\%) & $18(54.5)$ & 0 & $0.000^{*}$ \\
\hline Bone age (mean $\pm \mathrm{SD}$ ) years & $8.4 \pm 2.9$ & $9.5 \pm 1.3$ & 0.883 \\
\hline Serum ferritin (mean $\pm \mathrm{SD}$ ) $\mathrm{ng} / \mathrm{ml}$ & $674.7 \pm 338$ & $34 \pm 6.4$ & $0.000^{*}$ \\
\hline $\mathrm{T} 3($ mean $\pm \mathrm{SD}) \mathrm{ng} / \mathrm{dl}$ & $1.4 \pm 0.77$ & $1.3 \pm 0.6$ & 0.544 \\
\hline $\mathrm{T} 4($ mean $\pm \mathrm{SD}) \mathrm{ng} / \mathrm{dl}$ & $5 \pm 1.8$ & $4.8 \pm 2$ & 0.467 \\
\hline $\mathrm{TSH}($ mean $\pm \mathrm{SD}) \mathrm{mIU} / \mathrm{L}$ & $6.5 \pm 2.4$ & $6 \pm 1.9$ & 0.675 \\
\hline IGF1 (mean \pm SD) ng/ml & $138.2 \pm 75.9$ & $345.5 \pm 84.6$ & $0.022^{*}$ \\
\hline IGF1 SDS (mean \pm SD) & $0.006 \pm 0.1$ & $0.016 \pm 0.4$ & \\
\hline IGFBP3 (mean \pm SD) ng/ml & $587.4 \pm 292.2$ & $897 \pm 156.5$ & $0.037^{*}$ \\
\hline IGFBP3 SDS (mean \pm SD) & $0.0016 \pm 0.44$ & $0.041 \pm 0.2$ & \\
\hline
\end{tabular}

$\mathrm{SD}=$ standard deviation, ${ }^{*}$ statistically significant. $\mathrm{SDS}=$ Standard deviation score 
Table 2. The clinical and laboratory data of the two beta-Thalassemia major (BTM) groups

\begin{tabular}{|c|c|c|c|}
\hline Data groups & BTM group $1(n=19)$ & BTM group $2(n=14)$ & $\mathrm{P}$ \\
\hline Age (mean $\pm S D)$ years & $12.58 \pm 2.62$ & $7.8 \pm 3.9$ & 0.053 \\
\hline Male/female ratio & $10 / 8$ & $9 / 6$ & 0.745 \\
\hline Height (mean \pm SD) $\mathrm{cm}$ & $129 \pm 10.4$ & $113.93 \pm 12.5$ & 0.064 \\
\hline Wight (mean $\pm S D$ ) kg & $28.7 \pm 5.31$ & $20.5 \pm 6.8$ & 0.057 \\
\hline BMI (mean \pm SD) & $16.6 \pm 2.1$ & $16.1 \pm 1.8$ & 0.801 \\
\hline US/LS ratio (mean \pm SD) & $0.81 \pm 0.11$ & $0.92 \pm 0.27$ & 0.867 \\
\hline \multicolumn{4}{|l|}{ Pubertal stage: } \\
\hline Pre-pubertal (\%) & $3(15.8)$ & $5(35.7)$ & $0.045^{\star}$ \\
\hline Pubertal (\%) & $2(10.5)$ & $8(57.2)$ & $0.01^{*}$ \\
\hline Delayed puberty (\%) & $14(73.7)$ & $1(7.1)$ & $0.001^{*}$ \\
\hline Number with splenectomy (\%) & $12(67)$ & $6(43)$ & 0.059 \\
\hline Duration of transfusion & $10.32 \pm 2.6$ & $6.57 \pm 2.7$ & $0.043^{*}$ \\
\hline Frequancy of transfusion & $1.53 \pm 0.77$ & $1.5 \pm 0.52$ & 0.543 \\
\hline Duration of chelation & $6.27 \pm 2.26$ & $3.6 \pm 2.1$ & $0.001^{*}$ \\
\hline Bone age (mean $\pm S D$ ) years & $8.8 \pm 3$ & $7.2 \pm 2.4$ & 0.781 \\
\hline Serum ferritin (mean $\pm \mathrm{SD}$ ) $\mathrm{ng} / \mathrm{ml}$ & $602.2 \pm 210.4$ & $763.8 \pm 231.4$ & 0.611 \\
\hline T3 (mean \pm SD) ng/dl & $1.26 \pm 0.66$ & $1.36 \pm 0.79$ & 0.451 \\
\hline T4 (mean \pm SD) ng/dl & $4.91 \pm 1.8$ & $5.13 \pm 1.97$ & 0.545 \\
\hline TSH (mean \pm SD) mIU/L & $6.1 \pm 2.6$ & $7.04 \pm 2$ & 0.658 \\
\hline IGF1 (mean \pm SD) ng/ml & $112.2 \pm 82.2$ & $146.3 \pm 66.5$ & 0.096 \\
\hline IGF1 SDS(mean \pm SD) & $-0.19 \pm 0.3$ & $0.08 \pm 1.4$ & \\
\hline IGFBP3 (mean \pm SD) ng/ml & $517 \pm 156.5$ & $616.64 \pm 135.3$ & 0.134 \\
\hline IGFBP3 SDS (mean \pm SD) & $-0.02 \pm 0.5$ & $0.037 \pm 0.2$ & \\
\hline
\end{tabular}

SD: Standard deviation, *: statistically significant.

Table 3. Clinical and laboratory data of the beta-Thalassemia major (BTM) group 1 and its control group 3

\begin{tabular}{|c|c|c|c|}
\hline Data groups & BTM group $1(n=19)$ & Control group $3(n=18)$ & $\mathrm{P}$ \\
\hline Age (mean $\pm S D$ ) years & $12.58 \pm 2.62$ & $8.1 \pm 1.4$ & $0.042^{*}$ \\
\hline Male/female ratio & $10 / 9$ & $9 / 9$ & 0.761 \\
\hline Height (mean \pm SD) cm & $129 \pm 10.4$ & $126.6 \pm 9.7$ & 0.931 \\
\hline Wight (mean \pm SD) kg & $28.7 \pm 5.31$ & $26.2 \pm 4.5$ & 0.731 \\
\hline BMI (mean \pm SD) & $16.6 \pm 2.1$ & $15.9 \pm 1.8$ & 0.677 \\
\hline US/LS ratio (mean \pm SD) & $0.81 \pm 0.11$ & $0.79 \pm 0.23$ & 0.643 \\
\hline \multicolumn{4}{|l|}{ Pubertal stage: } \\
\hline Pre-pubertal (\%) & $3(15.8)$ & $14(77.8)$ & $0.001^{*}$ \\
\hline Pubertal (\%) & $2(10.5)$ & $4(22.2)$ & 0.071 \\
\hline Delayed puberty (\%) & $14(73.7)$ & $0(0)$ & $0.000^{*}$ \\
\hline Number with splenectomy (\%) & 12 ( 67) & $0(0)$ & $0.000^{*}$ \\
\hline Duration of transfusion & $10.32 \pm 2.6$ & 0 & $0.000^{*}$ \\
\hline Frequancy of transfusion & $1.53 \pm 0.77$ & 0 & $0.000^{*}$ \\
\hline Duration of chelation & $6.27 \pm 2.26$ & 0 & $0.000^{*}$ \\
\hline Bone age (mean $\pm S D$ ) years & $8.8 \pm 2$ & $8 \pm 1.3$ & 0.833 \\
\hline Serum ferritin (mean $\pm \mathrm{SD}$ ) $\mathrm{ng} / \mathrm{ml}$ & $602.2 \pm 210.4$ & $35 \pm 13$ & $0.000^{*}$ \\
\hline T3 (mean \pm SD) ng/dl & $1.26 \pm 0,66$ & $1.3 \pm 0.45$ & 0.541 \\
\hline $\mathrm{T} 4($ mean $\pm \mathrm{SD}) \mathrm{ng} / \mathrm{dl}$ & $4.91 \pm 1.8$ & $5.1 \pm 1.7$ & 0.677 \\
\hline $\mathrm{TSH}($ mean $\pm \mathrm{SD}) \mathrm{mIU} / \mathrm{L}$ & $6.1 \pm 2.6$ & $6.4 \pm 3$ & 0.788 \\
\hline IGF1 (mean \pm SD) ng/ml & $112.2 \pm 82.2$ & $159 \pm 79$ & 0.178 \\
\hline IGF1 SDS(mean \pm SD) & $-0.19 \pm 0.3$ & $-0.17 \pm 0.5$ & \\
\hline IGFBP3 (mean \pm SD) ng/ml & $517 \pm 156.5$ & $685 \pm 133$ & 0.271 \\
\hline IGFBP3 SDS (mean \pm SD) & $-0.02 \pm 0.5$ & $-0.01 \pm 0.7$ & \\
\hline
\end{tabular}

SD: Standard deviation, * : Statistically significant. 
Table 4. Clinical and laboratory data of the beta-Thalassemia major (BTM) group 2 and its control group 4

\begin{tabular}{|c|c|c|c|}
\hline Groups, Data & BTM group $2(n=14)$ & Control group $4(n=12)$ & $P$ \\
\hline Age (mean $\pm S D)$ years & $7.8 \pm 3.9$ & $8.8 \pm 2.4$ & 0.591 \\
\hline Male/female ratio & $8 / 6$ & $6 / 6$ & 0.892 \\
\hline Height (mean $\pm \mathrm{SD}$ ) $\mathrm{cm}$ & $113.93 \pm 12.5$ & $119 \pm 10.4$ & 0.234 \\
\hline Wight (mean \pm SD) kg & $20.5 \pm 6.8$ & $22.4 \pm 5.2$ & 0.865 \\
\hline $\mathrm{BMI}($ mean $\pm \mathrm{SD})$ & $16.1 \pm 1.8$ & $17 \pm 2$ & 0.787 \\
\hline US/LS ratio (mean \pm SD) & $0.92 \pm 0.27$ & $0.88 \pm 0.2$ & 0.901 \\
\hline \multicolumn{4}{|l|}{ Pubertal stage: } \\
\hline Pre-pubertal (\%) & $5(35.7)$ & $4(33)$ & 0.338 \\
\hline Pubertal (\%) & $8(57.2)$ & $8(67)$ & 0.851 \\
\hline Delayed puberty (\%) & $1(7.1)$ & & 0.05 \\
\hline Number with splenectomy (\%) & $6(43)$ & 0 & 0.001 \\
\hline Duration of transfusion & $6.57 \pm 2.7$ & 0 & $0.000^{*}$ \\
\hline Frequancy of transfusion & $1.5 \pm 0.52$ & 0 & $0.01^{*}$ \\
\hline Duration of chelation & $3.6 \pm 2.1$ & 0 & $0.000^{*}$ \\
\hline Bone age (mean $\pm S D$ ) years & $7.6 \pm 3.5$ & $8.6 \pm 1.9$ & 0.455 \\
\hline Serum ferritin (mean $\pm \mathrm{SD}$ ) $\mathrm{ng} / \mathrm{ml}$ & $763.8 \pm 231.4$ & $29 \pm 11$ & $0.000^{*}$ \\
\hline $\mathrm{T} 3($ mean $\pm \mathrm{SD}$ ) ng/dl & $1.36 \pm 0.79$ & $1.45 \pm 0.69$ & 0.708 \\
\hline $\mathrm{T} 4($ mean $\pm \mathrm{SD}) \mathrm{ng} / \mathrm{dl}$ & $5.13 \pm 1.97$ & $4.2 \pm 1.61$ & 0.521 \\
\hline $\mathrm{TSH}($ mean $\pm \mathrm{SD}) \mathrm{mlU} / \mathrm{L}$ & $7.04 \pm 2$ & $6.8 \pm 2.3$ & 0.568 \\
\hline IGF1 (mean \pm SD) ng/ml & $146.3 \pm 66.5$ & $232 \pm 58$ & 0.062 \\
\hline IGF1 SDS(mean $\pm S D$ ) & $0.08 \pm 1.4$ & $0.09 \pm 1.1$ & \\
\hline IGFBP3 $($ mean \pm SD) ng/ml & $616.64 \pm 135.5$ & $681 \pm 177$ & 0.446 \\
\hline IGFBP3 SDS (mean \pm SD) & $0.37 \pm 1.2$ & $0.51 \pm 1.36$ & \\
\hline
\end{tabular}

SD: Standard deviation, ${ }^{*}$ statistically significant. SDS = Standard deviation score.

Table 5. Correlation between the clinical parameters of beta-Thalassemia major group and their studied laboratory parameters.

\begin{tabular}{lllllll}
\hline Versus & Ferritin & T3 & T4 & TSH & IGF1 & IGFBP3 \\
\hline Age & 0.1288 & -0.0773 & 0.0142 & -0.09768 & 0.29596 & 0.0914 \\
Sex & -0.1431 & 0.0227 & 0.01416 & $-0.3686^{*}$ & 0.296 & 0.2089 \\
Height & 0.21433 & -0.0261 & 0.0631 & -0.16037 & $0.3172^{*}$ & 0.1239 \\
Weight & 0.21532 & -0.0339 & 0.1700 & -0.10446 & 0.2698 & 0.1263 \\
BMl & 0.0848 & -0.1309 & -0.0223 & -0.1491 & 0.02717 & -0.1632 \\
Duration of transfusion & 0.1414 & -0.0461 & -0.01713 & -0.0772 & $0.4181^{*}$ & 0.09813 \\
Frequency of transfusion & 0.12622 & -0.0593 & -0.2285 & 0.10061 & -0.1181 & -0.2711 \\
Duration of chelation & 0.1432 & -0.0327 & 0.0751 & -0.01931 & $0.49898^{*}$ & 0.1461 \\
U /L ratio & 0.14822 & 0.0454 & $0.4636^{*}$ & 0.05135 & -0.30203 & -0.213 \\
T3 & -0.10281 & 1 & 0.06362 & -0.1291 & 0.02122 & -0.11744 \\
T4 & -0.1177 & -0.0636 & 1 & 0.2093 & 0.10298 & 0.2183 \\
TSH & -0.14556 & -0.1291 & 0.2093 & 1 & -0.1537 & -0.26611 \\
IGF1 & 0.2244 & 0.02122 & 0.10298 & -0.1537 & 1 & 0.1072 \\
IGFBP3 & -0.235 & -0.1174 & 0.2183 & -0.26611 & 0.1072 & 1 \\
\hline
\end{tabular}

${ }^{*}$ Correlation is significant at the 0.05 level (2 tailed). 


\section{DISCUSSION}

In our study, no significant difference was found between the mean heights of the group of BTM as a whole and the control group, but there was a statistical significant decrease in the upper / lower segment ratio $(p=0.035)$, this can be explained by what was reported by Low, $2005^{10}$ as there was disproportionate truncal shortening due to platyspondyle resulting from a combination of factors like hemosiderosis, desferoxamine toxicity or trace elements deficiency in those patients with BTM.

There were a significant proportion of our patients with BTM with delayed puberty rather than pre-pubertal $(45.5 \%)$, this agreed with the study of Aydinok et al 2002, ${ }^{11}$ where they attributed the cause to excess iron deposition in the hypothalamus, pituitary and gonads.19 $(57.6 \%)$ of our studied children with BTM were with short stature, usually children with BTM frequently have growth retardation in-spite of hyper-transfusion and intensive chelation therapy, ${ }^{12}$ the etiology of this growth retardation has included; iron toxicity, delayed puberty, thyroid abnormalities and impaired growth hormone responses. ${ }^{13}$ In the present study, there was no overt hypothyroidism in our patients with BTM, the result which agreed with that of Bronspiegel-Weintrobe et al $1990,{ }^{14}$ but the study of Aydinok et al 2002 11 declared that $17-18 \%$ of their patients with betathalassemia have hypothyroidism. IGF1 was statistically significantly lower in our children patients with BTM than the control group $p<0.03$, the result which agreed with that of DeLuca et al $1995,{ }^{15}$ who attributed this low level to disturbed liver function secondary to iron overload and malnutrition. IGFBP3 in our study was also statistically significantly lower than in the control group $p<0.05$, the result which agreed with that of Chrysis et al $2001^{13}$ who found low levels of IGF1 and IGFBP3 in their thalassemia patients with short stature and decelerated growth compared to those with normal growth.

Not all of our thalassemia patients were with retarded linear growth, $57.6 \%$ were below the 5th percentile for age and sex (BTM group1), the mean age of them was higher than the rest of the group (BTM group 2), Soliman et al $1999^{16}$ reported that after the age of four, there is significant growth retardation involved short stature and sitting height. This age difference between the two thalassemia groups in our study, may explain the insignificant difference between the two groups as regard serum levels of IGF1 and IGFBP3, as IGF1 and IGFBP3 are known to increase slowly with age in childhood, reaching a peak level at puberty and decrease thereafter. ${ }^{17}$
In the present study $18(60 \%)$ of the control group were with short stature (below the 5th percentile for age and sex), without any pathological cause, so they grouped as idiopathic short stature (ISS), this also was reflected on the difference between the two studied groups as regard bone age which was insignificant, as there is wide variation in bone age delay in the group with ISS. ${ }^{18}$ There was also insignificant difference between group1 of BTM patients and its control group 3 as regard serum levels of IGF-1, the result which agreed with that of Chrysis et al $2001^{13}$ and that of Agular-Oliveira et al, $1999^{19}$ who found Low plasma levels of IGF1 in ISS. Gucevzs et al $1997^{20}$ explained this result by disorders at the level of $\mathrm{GH}$ signal transduction, causing selective inhibition of IGF1 rather than of IGFBP3. Serum parameters of group 2 of patients with BTM, in our study were insignificantly different from their control group 4 except as regard serum ferritin; this ferritin was accused in several studies before to be the cause of short stature and decreased their serum levels of IGF-1 and its binding protein IGFBP-3. ${ }^{16}$ In our study there was no correlation between serum ferritin and any other variable of the patients with BTM, the result which agreed with that of Karydis et al $2004^{21}$ and that of Vedergor et al 2007, ${ }^{22}$ who found no significant correlation between serum ferritin and the peak levels of GH or IGF1. In our study there was a statistically significant correlation between T4 and upper/lower segment ratio, this result could be explained by the known effect of thyroid hormone on the body proportions..$^{23}$ The serum levels of IGF-1 in our study were statistically significantly correlated with the heights of the patients, it was mentioned before that increased IGF-1was associated with increased height in both white and black men; ${ }^{24}$ also in our results IGF-1 serum levels also were significantly correlated with the duration of the transfusion and duration of chelation therapy $p<0.05$, the parameters of disease duration which are highly significantly correlated with the age of the patients and it was mentioned in several studies that IGF-1 increases with age, and it reaches the highest point during puberty and decrease thereafter. ${ }^{24,17}$

In conclusion, growth retardation in children with BTM is evident despite regular transfusions and chelation therapy, especially in children with older age and the cause is mainly in growth hormone-IGF1 and IGFBP3 axis. Further studies are required to find the possibility of using human recombinant IGF-1 for those patients with BTM and patients with growth hormone insensitivity. 


\section{REFERENCES}

1. Rund D. Beta-thalassemia. N Engl J Med 2005;353 (13):1135-46.

2. Loluis CK. Puberty and endocrine function in Bthalassemia major. J Pediatric Endocrinol Metab 1997;10(1):175-84.

3. Shalitin S, Carmi D, Weintrob N, et al. Serum feritin level as a predictor of impaired growth and puberty in thalassemia major patients. Eur J Haematol 2005; 74(1):93-100.

4. Wonke B. Clinical management of B-Thalassemia major. Semin Hematol 2001 38:450-359.

5. Raiola G, Galati MC, De Sanctis V, et al. Growth and puberty in thalassemia major. J Pediatr Endocrinol Metab 2003;Suppl 2:259-66.

6. Soliman AT, El Banna N, Ansari BM. GH response to provocation and circulating IGF-1 and IGFBP-3 concentrations, the IGF-1 generation test and clinical response to $\mathrm{GH}$ therapy in children with beta thalassemia. Eur J Endocrinol 1998; 138(3):384- 400.

7. White D, Kramer D, Johnson G, Dick F, Hamilton H. Prediction of bone marrow iron findings from tests performed on peripheral blood. Am J Clin Pathol 1986;72(3):346-51.

8. Gruhn JG, Barsano CP and Kumar Y. The development of tests of thyroid function. Arch Pathol Lab Med 1987;111(1):84- 100.

9. Gruelich WW, Pyle SI (1974): Radiographic Atlas of Skeletal Development of the Hand and Wrist. San Francisco, Stanford University Press. P.p.87-91.

10. Low LC. Growth of children with beta-thalassemia major. Indian J Pediatr 2005; 72(2): 159-64.

11. Aydinok Y, Darcan S, Polat A, et al. Endocrine complications in patients with beta-thalassemia major. $\mathrm{J}$ Trop Pediatr 2002; 48(1): 50-4.

12. Kattamis C, Liakopoulou T, Kattamis A. Growth and development in children with thalassemia major. Acta Paediatr Scand 1990; 366(Suppl 12):111-7.

13. Chrysis DC, Alexandrides TK, Koromantzou E, et al. Novel application of IGF-1 and IGFP-3 generation tests in the diagnosis of growth hormone axis disturbances in children with beta-thalassaemia. Clin Endocrinol (Oxf). 2001;54(2):253-9.

14. Bronspiegel-Weintrob N, Olivieri NF, Tyler B, Andrews $\mathrm{DF}$, Freedman $\mathrm{MH}$. Holland FJ. Effect of age at the start of iron chelation therapy on gonadal function in beta-thalassaemia major. New Eng J Med 1990;323, 713-9.

15. DeLuca G, Maggiolini M, Bria M, et al. GH secretion in thalassemia patients with short stature. Horm Res 1995;44(4):158-63.

16. Soliman AT, elzalabany MM, Mazlom Y, et al. Spontaneous and provoked growth hormone $(\mathrm{GH})$ secretion and insulin-like growth factor 1 (IGF-1) concentration in patients with beta thalassemia and delayed growth. J Trop Pediatr 1999; 45(6):327-37.

17. Yuksel B, M. Ozbek MN, Mungan NO, et al. Serum IGF-1 and IGFBP-3 Levels in healthy children between 0 and 6 years of age. $\mathrm{J}$ Clin Res Pediatr Endocrinol 2011;3(2):84-8.

18. Caliebe J, Martin DD, Ranke MB, Wit JM. The Auxological and biochemical continuum of short children born small for gestational age (SGA) or with normal birth size (Idiopathic short stature). Int J Pediatr Endocrinol 2010; 2010:852967.

19. Agular-Oliveira MH, Gill MS, de A Barretto ES, et al. Effect of severe growth hormone $(\mathrm{GH})$ deficiency due to a mutation in the $\mathrm{GH}$-releasing hormone receptor on insulin-like growth factors (IGFs), IGF-binding protiens, and ternary complex formation throughout life. J Clin Endocrinol Metab 1999; 84(11):4118-26.

20. Gucev ZS, Oh Y, Kelley KM, Labarta JI, Vorwerk P, Rosenfeld RG. Evidence for insulin-like growth facror (IGF)-independent transcriptional regulation of IGF binding protein-3 by growth hormone in SKHEP-1 human hepatocarcinoma cells. Endocrinology 1997;138(4):1464-70.

21. Karydis I, Karagiorga-Lagna M, Nounopoulos C, Tolis G. Basal and stimulated levels of growth hormone, insulin-like growth factor-1(IGF-1), IGF-binding proteins in beta-thalassemia major. J Pediatr Endocrinol Metab 2004; 17(1):17-25.

22. Vidergor G, Goldfarb AW, Glaser B, Dresner-pollak R. Growth hormone reserve in adult beta-thalassemia patients. Endocrine 2007; 31(1):33-7.

23. William F Ganong. Review of Medical Physiology. $22^{\text {nd }}$ edition 2005 Chapter 22 P 406.

24. Gapstur SM, Kopp P, Chiu BC, Gann PH, Colangelo LA, Liu K. Longitudinal associations of age, anthropometric and lifestyle factors with serum total insulinlike growth factor-I and IGF binding protein-3 levels in Black and White men: the CARDIA Male Hormone Study. Cancer Epidem Biomar 2004;13(12):2208-16. 